\title{
OS XIKRIN DA IERRA INDÍGENA TRINCHEIRA-BACAJÁ E OS ESTUDOS COMPLEMENTARES DO RIO BACAJÁ: REFLEXÕES SOBRE A ELABORACÃO DE UM LAUDO DE IMPACTO AMBIENTAL
}

\section{Thais Mantovanelli* \\ Universidade Federal de São Carlos - Brasil}

Resumo: Como se produz um estudo de impacto ambiental? O objetivo aqui é apresentar o processo de elaboração de dados e redação dos Estudos Complementares do Rio Bacajá, um estudo de impacto ambiental realizado na Terra Indigena TrincheiraBacajá decorrente da construção do Aproveitamento Hidrelétrico de Belo Monte na região do Médio Xingu. Através do acompanhamento das equipes de especialistas nas aldeias, durante a etapa de coleta de dados, e do descontentamento dos Xikrin com o resultado final do laudo, intenta-se problematizar a forma de realização desse tipo de documento. Como garantir a presença e a voz dos conhecimentos dos povos indígenas nesses processos? Com essa questão colocada pelos Xikrin, durante a apresentação do resultado final dos Estudos, pretendo tornar visiveis as teorias dos Xikrin sobre a relação hidrológica do rio Bacajá com o rio Xingu e suas previsões de impacto, que foram obliteradas pela versão final do documento.

Palavras-chave: etnologia indigena, laudo de impacto ambiental, regimes de conhecimento, Xikrin Mẽbêngôkre.

Abstract: How is produced an Environmental Impact Inquiry? The aim here is to bring forward the process of elaboration and composition of the Complementary Studies on Bacajá River, an inquiry of environmental impact that was conducted in the Trincheira-Bacajá's Indigenous Territory as part of the process of building the Belo Monte Hydroelectric Plant in Xingu River. By monitoring teams of specialists

* Doutoranda em Antropologia Social (pesquisadora e bolsista Capes). Contato: thaisremantovanelli@ gmail.com

Horizontes Antropológicos, Porto Alegre, ano 22, n. 46, p. 159-188, jul./dez. 2016 http://dx.doi.org/10.1590/S0104-71832016000200006 
in the villages during the data collection stages, allied to the clear discontent of the Xikrin Indians with the final report, this article intends to reflect critically on this kind of inquiry. How can we guarantee the presence and the voice of indigenous knowledge in those documents? As the Xikrin Indians had put this issue, my aim is to make visible the Xikrin theories on the hydrological relations between the Bacajá and Xingu Rivers and their foreknowledge of hazards, both of them obliterated on the final version of the document.

Keywords: environmental impact inquiry, ethnology, knowledge systems, Xikrin Indians.

Os Xikrin da Terra Indígena Trincheira-Bacajá chamam a usina hidrelétrica de Belo Monte de ngô beyêt ${ }^{1}$ (água barrada) e acionam outras designações de tradução ampliando a significação do termo para "água podre, água suja, água velha, água parada". Água podre, suja, velha e parada é o espectro de Belo Monte sobre o seu rio, uma previsão acurada que nenhum cálculo técnico de "impacto da obra" consegue, ou quer, apurar. ${ }^{2}$ Mas os Xikrin ${ }^{3}$ insistem em comunicar aos técnicos a sua assustadora visão de futuro, seja em ocupações do canteiro de obra, em comunicados à imprensa ou reuniões formais com os técnicos.

1 Existe grande variedade no modo de grafia da língua mẽbêngôkre nos trabalhos antropológicos. Tal variedade é resultado do grande conjunto de pesquisas que tem utilizado padrões distintos de grafia, especialmente após o registro pelo Summer Institute of Linguistics da língua mẽbêngôkre-kayapó. Ao longo deste trabalho, procuro manter o modo de grafia usada por cada autor, exceto para os casos de uso dos termos pelos interlocutores dessa pesquisa. Mesmo sabendo não ser convencional mostrar as diferenças em relação ao modo de grafia da língua nativa, minha intenção é destacar que os Xikrin têm discutido o modo correto de grafia de sua língua e têm testado a padronização desse modo através do registro em formas variadas. Vale a pena mencionar que um projeto linguístico de padronização é desejado por eles.

2 Este artigo é parte do argumento em desenvolvimento de minha pesquisa de doutorado intitulada $O s$ Xikrin do Bacajá e a Usina Hidrelétrica de Belo Monte: uma crítica indígena à política dos brancos, em fase final de redação da tese. Agradeço à leitura e comentários das versões preliminares do artigo realizadas por Clarice Cohn, Catarina Morawska Vianna, Felipe Vander Velden, Geraldo Andrello, Jorge Vilella e a todos os membros do grupo de pesquisa Hybris (Grupo de Estudo e Pesquisa sobre Relações de Poder, Conflitos, Socialidades), especialmente a Sara Munhoz, Jacqueline Stefanny Ferraz de Lima e Clarissa Martins. Agradeço também aos comentários de Orlando Calheiros, Ana Carneiro, Messias Basques e às sugestões dos pareceristas.

3 Quando eu utilizar a nominação Xikrin é para me referir aos Xikrin da Terra Indígena Trincheira-Bacajá; quando for me referir aos Xikrin da região do rio Cateté, usarei Xikrin do Cateté.

Horizontes Antropológicos, Porto Alegre, ano 22, n. 46, p. 159-188, jul./dez. 2016 
Com efeito, desde a retomada das negociações para construção de Belo Monte, os Xikrin, bem como os demais grupos indígenas da região de Altamira (PA), ${ }^{4}$ têm se deparado com uma enorme quantidade de reuniões com agências do governo e empresas responsáveis pela construção da usina. Em tais reuniões, ocorridas principalmente após o ano de 2008, os técnicos lhes mostraram, por meio de tabelas e gráficos, as previsões de impactos causados pelo empreendimento, bem como as propostas de medidas de compensação.

Em junho de 2012, devido ao atraso das ações mitigatórias, esses grupos indígenas realizaram uma ocupação em um dos sítios de construção da usina paralisando parcialmente a obra durante 21 dias, reivindicando o cumprimento de alguns programas de mitigação e das condicionantes. As condicionantes foram estabelecidas pela Fundação Nacional do Índio (Funai) em um documento intitulado Parecer técnico 21, ${ }^{5}$ Nesse documento, a Funai (2009) aprovou a continuação de licenciamento da hidrelétrica, desde que a empresa acionista do empreendimento cumprisse 40 condicionantes referentes a políticas de mitigação e execução de um laudo de estudo de impacto ambiental na Terra Indígena Trincheira-Bacajá.

O presente artigo trata do processo de produção desse laudo de impacto ambiental, na Terra Indígena Trincheira-Bacajá, nominado Estudos Complementares do Rio Bacajá (Leme Engenharia, 2012). O estudo teve início no ano de 2011 e contou com minha participação como "acompanhamento antropológico" e com "coordenação antropológica" de Clarice Cohn. ${ }^{6}$

Durante o processo de elaboração dos Estudos Complementares do Rio Bacajá, eu presenciei algumas situações de equívocos entre os Xikrin, as

4 Os povos da chamada região da Volta Grande do Xingu são: os Juruna (TIs Paquiçamba e KM 17); os Arara (TIs Arara, Cachoeira Seca e Arara da Volta Grande); os Xikrin (TI Trincheira-Bacajá); os Assurini (TI Koatinemo); os Kayapó (TI Kararaô); os Parakanã (TI Apyterewa); os Araweté (TI Araweté do Ipixuna); os Xipaia (TI Xipaia); os Kuruaia (TI Kuruaia). Para visualização do mapa da região: http:// www.socioambiental.org/esp/bm/loc.asp.

5 O parecer é uma solicitação do Instituto Brasileiro de Recursos Renováveis (Ibama), órgão licenciador do AHE Belo Monte (Aproveitamento Hidrelétrico de Belo Monte), para a emissão do termo de referência específico para o componente indígena, do qual depende a licença de instalação para realização da obra. O documento foi emitido em 30 de setembro de 2009.

6 Clarice Cohn tem trabalhado junto aos Xikrin desde o início de sua formação como antropóloga, tendo produzido dissertação de mestrado e tese de doutorado, além de livros e diversos artigos, a partir de suas pesquisas. Para alguns exemplos: Cohn (2000, 2001, 2005, 2010). Atualmente, organizou, juntamente com João Pacheco de Oliveira, um dossiê sobre Belo Monte e a questão indígena; ver Oliveira e Cohn (2014).

Horizontes Antropológicos, Porto Alegre, ano 22, n. 46, p. 159-188, jul./dez. 2016 
equipes para coleta de dados e os engenheiros redatores do laudo. As teorias dos Xikrin sobre os impactos causados pela construção de Belo Monte e suas análises sobre a relação hidrológica dos rios Bacajá (onde se situa a Terra Indígena) e Xingu (onde o complexo hidrelétrico está sendo construído) foram obliteradas na versão final do documento, que dá destaque aos cálculos matemáticos apresentados por meio de gráficos realizados pelos engenheiros responsáveis.

A fim de evidenciar o eclipsamento das teorias xikrin na versão final do documento, que responde a uma estética de organização de dados e de modelos matemáticos para previsões de impactos, tomo emprestada a mais recorrente tríade classificatória dos Xikrin Mẽbêngôkre. A tríade é composta por três conceitos classificatórios que são acionados por eles tanto enquanto processos de adjetivação de bens, relações, coisas, pessoas, acontecimentos, como processo de substantivação.

Assim, as terminologias mejx/mejxtere, designam a beleza, o belo, modos corretos, o verdadeiro ou a verdade; punú/punure designa a feiura, o horrível, modos errôneos; kaigo, por sua vez, designa falsidade, fraude, fraudulento, enganador, falso, fajuto, malfeito.

Os Xikrin empregam a tríade classificatória para adjetivar uma ampla gama de relações: deles entre si, deles com outras pessoas, deles com coisas e objetos, deles com fenômenos naturais, e, principalmente de seu modo de conhecimento com outros modos. Desde os primeiros momentos de pesquisa de campo, os etnógrafos dos Xikrin são ensinados a também classificarem o mundo a partir da tríade. Ensinam-nos a dizer quando uma carne é boa (mrü mejx), uma criança é bonita (meprire mejxetere), um ritual está correto (metoro mejxkumren); quando uma fala está incoerente (kaben kaigo), quando se faz algo equivocadamente (ipey kaigo); quando uma fala é feia (kaben punú), quando se faz algo errado (ipey punure); e assim sucessivamente.

Minha intenção ao acionar a tríade classificatória xikrin para descrever o processo de elaboração do estudo de impacto ambiental, os Estudos Complementares do Rio Bacajá, é tanto tornar visível o ponto de vista dos Xikrin sobre tal processo, mostrando o que ficou obliterado na versão final do documento, quanto realizar uma contribuição analítica sobre processos de obliteração de informação na composição de documentos, discutida recentemente na antropologia, especialmente nos trabalhos de Marilyn Strathern (1991, 2000) e Annelise Riles (2001, 2006). 
Para cumprimento de sua proposta, este artigo divide-se em cinco partes. A primeira apresenta a importância da tríade classificatória na cosmologia mẽbengôkre, destacando a noção de kukràdjà, traduzida geralmente como cultura/conhecimento tipicamente mébengôkre. A segunda parte, que é atribuída ao classificador kaigo (falso, fraudulento), apresenta a crítica dos Xikrin em relação ao modo como eles foram alocados em relação ao grid (quadro de referência) de povos diretamente impactados para indiretamente impactados pela construção de Belo Monte e a importância do Parecer técnico 21, de autoria da Funai (2009). A terceira parte, atribuída ao classificador mejx/mejxtere (belo, correto, bom), descreve o modo de coleta de dados das equipes de especialistas em campo e o envolvimento dos Xikrin com tais atividades. A quarta parte, vinculada ao classificador punú/punure (feio, errado) discute a estética final dos Estudos Complementares do Rio Bacajá e o eclipsamento dos saberes xikrin sobre o rio Bacajá, suas teorias de impacto e a relação hidrológica com o rio Xingu. A quinta parte apresenta algumas considerações sobre a diferença de tratamento que os conhecimentos xikrin tiveram na versão final dos Estudos Complementares do Rio Bacajá em relação aos cálculos matemáticos e gráficos de vazão do rio feitos pelos engenheiros redatores.

\section{Kukràdjà, a cultura (dos) Mêbengôkre}

A Terra Indígena Trincheira-Bacajá é situada ao longo do rio Bacajá e conta com oito aldeias em seu curso. O rio Bacajá é afluente da margem direita do rio Xingu em sua Volta Grande. A chegada dos Xikrin à região do rio Bacajá, como mostra Fisher (2000), tem como data aproximada meados da década de 1920. Antes do contato com a sociedade nacional, ocorrido a partir de 1959 e 1961, os Xikrin viviam caminhando por toda a região de floresta ao longo da margem do rio e no interior de seus igarapés. Nessas andanças, segundo Fisher (2000) e Cohn (2005), os Xikrin promoveram e enfrentaram guerras com os povos vizinhos, especialmente os Araweté ( $k u b \tilde{e}$ kamrêk $^{7}$ ), Assurini (kubẽkakrit $\left.{ }^{8}\right)$ e Parakanã (kubẽ kakakôre $\left.{ }^{9}\right)$. Após o contato

\footnotetext{
Kubẽ (estrangeiro), kamrêk (vermelho): estrangeiro de corpo vermelho.

${ }^{8}$ Para Verswijver (1992), a terminologia refere-se a estrangeiros indígenas, gente não mẽbengôkre. No entanto, os Xikrin usam tal terminologia para designar especialmente os Assurini.

9 Estrangeiro com obstrução de lábio bloqueada por algo (no caso pedras alisadas).
} 
e aldeamento, a Terra Indígena Trincheira-Bacajá passa a compor o complexo multiétnico da região da Volta Grande do Xingu. ${ }^{10}$

Os Xikrin são um povo do tronco linguístico jê setentrional que, do mesmo modo como os Kayapó, se denominam Mebêngôkre. Atualmente, os Xikrin ocupam as Terras Indígenas Cateté, na região de Carajás e a Terra Indígena Trincheira-Bacajá, região de Altamira, ambas na Amazônia paraense.

A autodenominação Mẽbengôkre tem como tradução usual: "povo que saiu do buraco d'água" (Vidal, 1977). Os Xikrin e os Kayapó falam a língua mẽbengôkre (mẽbengôkre kaben) e compartilham certos aspectos da cultura como alguns grafismos corporais, mitologia, rituais, padrões de transmissão de nominação, forma organizacional das aldeias, forma de corte de cabelo, entre outros. Assim, Xikrin e Kayapó possuem/praticam/conhecem/compartilham kukràdjà (cultura/modo de conhecimento). Kukràdjà relaciona-se a um modo específico de vida, de estar no mundo, de conhecimento e de cultura, compartilhado entre os Mẽbengôkre (Cohn, 2010).

Apesar de reconhecerem-se como povo-parente que se dividiram em um dado momento mítico/histórico (Turner, 1992) e compartilharem mitos, padrões gráficos e estrutura linguística, os Xikrin e os Kayapó não se reconhecem como iguais. Ambos marcam essas diferenças em várias situações como nos usos de palavras distintas da língua mẽbengôkre, formas de escrita, padrões corporais gráficos, aspectos da ornamentação corporal, entre outros. Mesmo com essas diferenças, para os Xikrin, os Kayapó não são considerados estrangeiros (kubẽ), pois são mẽbengôkre, falantes da língua dos Mẽbengôkre.

Kukradjà é peça central do que Vidal (1977) chama de "ontologia Xikrin". Kukràdjà é a condição para produção de pessoas e coisas belas e é entendido como sendo as capacidades ou conhecimentos necessários para a ação correta na realização dessas produções. É comum, na bibliografia especializada, associar krukràdjà à tradução de conhecimento, envolvendo tanto conhecimentos rituais tradicionais quanto saber pilotar voadeiras (Gordon, 2011). Kukràdjà serve também como tradução para cultura, tradição, hábitos, práticas, conhecimentos, saberes, modos de vida. Mebêngôkre kukràdjà (conhecimento dos Mẽbengôkre) é a cultura que faz parte do modo de existência xikrin e kayapó. Para Turner (1991), associar kukràdjà à denominação de cultura, apesar dos

10 Ver nota 2. 
problemas semânticos que tal aproximação acarreta, é uma maneira de frisar um componente imaterial dos fenômenos, como algo que perdura, demora no tempo, formas que permanecem, conhecimentos necessários para recriação de corpos e objetos ao modo mebêngôkre. Kukràdjà refere-se tanto aos conhecimentos gerais, quanto aos conhecimentos específicos para cada classe de idade ou gênero. ${ }^{11}$

A noção de kukràdjà relaciona-se especificamente aos povos mẽbengôkre, xikrin e kayapó, sendo que os estrangeiros ( $k u b e \tilde{e})$, outros grupos indígenas não mẽbengôkre e brancos não detêm/praticam esse tipo de conhecimento/saber.

$\mathrm{O}$ termo kukràdjà, glosado pelos Xikrin como cultura ou conhecimento dos Mẽbengôkre, não se constitui num repertório fixo, estabelecido e transmitido através das gerações como réplica. Ao contrário, kukràdjà compreende um conjunto dinâmico de saberes e conhecimento, constantemente alterado por novos aportes, novos conhecimentos ou novas atribuições. ${ }^{12}$

A tríade classificatória; mejx/mejxtere (belo, correto), kaigo (fajuto, fraudulento), punú/punure (feio, errado) é acionada pelos Xikrin para definição dos vários tipos de estrangeiros com os quais se relacionam. Saber operar a tríade faz parte da cultura mẽbengôkre, faz parte de saber/conhecer/utilizar kukràdjà.

Desse modo, os Xikrin costumam classificar os estrangeiros (kubẽ), índios não mẽbengôkre e brancos a partir da relação que estes possuem com o modo de conhecimento kukràdjà. Assim, estrangeiros em geral são considerados como não conhecedores da cultura mẽbengôkre (mẽbengôkre kukràdjà mar kêt), não falantes da língua mẽbengôkre (mẽbengôkre kaben mar kêt), cuja extensão contrária é saber falar direito e de forma bela (kaben mejx). Existem algumas exceções: antropólogos que trabalham com eles e que, em certos

11 Terminologias mais usadas: me kuni kukràdà (conhecimento de todos); menõrõny kukràdjà (conhecimento dos jovens); metumre kukràdjà (conhecimento dos antigos); memy kukràdjà (conhecimentos dos homens); meni kukradja (conhecimento das mulheres). Atributos mais pessoais: $i$-kukràdjà (meu conhecimento); me õ kukràdjà (conhecimento de alguém).

12 Cohn $(2000,2005)$ reporta à abertura de tal conceito a exteriores, destacando procedimentos de preensões e promovendo um contraponto ao que ficou por muito tempo conhecido como "fechamento jê". O debate de Cohn (2005) insere-se numa crítica antropológica mais abrangente sobre o paradigma sociocêntrico atribuído aos povos de língua jê, por etnólogos inspirados nos aportes funcionalistas, estruturais e estrutural-funcionalistas. Durante a década de 1990 ocorre um movimento de revisão dessa herança centrípeta como designadora dos sistemas jê, associando o sistema a movimentos de captura e predação ou aspectos centrífugos do sistema de produção da sociedade. O trabalho de Coelho de Souza (2002) é um importante marco nesse debate.

Horizontes Antropológicos, Porto Alegre, ano 22, n. 46, p. 159-188, jul./dez. 2016 
casos, são considerados conhecedores da língua (mẽbengôkre kaben mar mejx) e sabedores de algumas partes da cultura mẽbengôkre (mẽbengôkre kukràdjà mar mejx); índios de outras etnias ou brancos que se casaram com pessoas mẽbengôkre e que aprenderam a viver entre eles, com eles e como eles; e alguns servidores da Funai, especialmente na época de existência de chefe de posto, quando se costumava passar determinados períodos morando nas aldeias.

Salvo as exceções, a grande maioria dos estrangeiros (kubẽ) é classificada como não conhecedores da cultura mẽbengôkre, da língua e dos modos corretos de falar. Alguns brancos, especialmente os engenheiros dos Estudos Complementares do Rio Bacajá, para o caso apresentado aqui, são considerados pelos Xikrin como não conhecedores da cultura mẽbengôkre, são considerados como os que falam de forma errada (kaben punure) e que não conhecem o rio Bacajá (ngô Bacajá mar kêt), nem a floresta da Terra Indígena, nem como vivem os animais e plantas da região.

Diferentemente dos estrangeiros (kubẽ), os Kayapó são classificados tanto como conhecedores e sabedores da cultura mẽbengôkre (kukràdjà mar mejx) quanto como fajutos, fraudulentos (kaigo). Tal possibilidade classificatória depende de cada situação específica. Um exemplo da classificação crítica dos Kayapó, como kaigo (fraudulento/falso), foi acionado pelos Xikrin, durante minha pesquisa de campo, quando os Kayapó quiseram juntar-se aos grupos indígenas da região de Altamira, durante a ocupação de Belo Monte em 2012. Através de conversas de rádio, os Kayapó tentaram convencer os Xikrin de que eles também tinham que participar da ocupação, porque também queriam parar Belo Monte. Os Kayapó disseram que com a presença deles na ocupação haveria muito mais recursos das ONGs e maior apoio do Instituto Socioambiental (ISA), com quem os Kayapó trabalham há bastante tempo e desenvolvem vários projetos de sustentabilidade ambiental, proteção territorial, revitalização cultural, e assim por diante. Os Xikrin foram enfáticos, negando a presença dos Kayapó durante a ocupação.

Os Kayapó não moram aqui, não moram onde está ngô beyêt [água parada, Belo Monte], não têm que vir aqui. Aqui, só devem estar os povos da região, ninguém mais. Nem Mundurucu e nem Kayapó, só a gente daqui. Kayapó fala que é parente mẽbêngôkre, sabe falar a língua mẽbêngôkre, mas fala de jeito falso [kaben kaigo] e faz as coisas de qualquer jeito [ipey kaigo] sem perguntar para os Xikrin. Kayapó tem que ficar lá na casa deles, cuidar do rio de lá e não daqui.

Horizontes Antropológicos, Porto Alegre, ano 22, n. 46, p. 159-188, jul./dez. 2016 
Assim como kukràdjà (cultura dos Mẽbengôkre) não é um conjunto fixo de repertórios de conhecimento e saberes, a classificação dos estrangeiros (kubẽ) e dos Kayapó não comporta uma taxonomia fixa, porque todos os classificadores são acionados em relação a uma situação específica.

Mesmo durante o processo de produção dos Estudos Complementares do Rio Bacajá, o uso de tais classificadores alterava-se conforme as relações e situações vividas pelos Xikrin em relação aos kubẽ (estrangeiros/brancos) envolvidos nesse processo: equipes de pesquisadores que visitavam as aldeias, engenheiros responsáveis pela confecção dos Estudos Complementares do Rio Bacajá, servidores da Funai local e de Brasília, funcionários da Norte Energia.

O que apresento a seguir mostra como esses classificadores podem ser mobilizados analiticamente para descrever o processo de produção dos Estudos Complementares do Rio Bacajá e visibilizar aquilo que ficou obliterado na versão final de redação do documento: as teorias dos Xikrin acerca dos impactos do rio Bacajá com construção de Belo Monte, os conhecimentos deles da região da Terra Indígena Trincheira-Bacajá, e a teoria xikrin da relação hidrológica do rio Bacajá com o rio Xingu.

\section{Parecer técnico 21: documento kaigo (falso/fraudulento). Os Xikrin como "povos geograficamente distantes da obra"}

O classificador kaigo (falso/fradulutento) é acionado nesta parte do artigo para apresentar o efeito da emissão de um documento, ${ }^{13}$ o Parecer técnico $21,{ }^{14}$ que garantiu aos Xikrin o direito à realização de um estudo de impacto em sua Terra Indígena, ao mesmo tempo em que os desclassificaram como "povos diretamente impactados pela obra".

${ }^{13}$ Em reconhecido artigo sobre o tratamento da antropologia a estudos com documentos e burocracia, Hull (2012) destaca o modo como esse interesse antropológico tem marcado as pesquisas atuais, destacando a questão dos efeitos gerados pela produção documental e a importância da materialidade que marcam essas pesquisas tratando documentos como artefatos (Riles, 2006). Documentos deixam de ser tratados como fornecedores neutros de discursos e passam a ser analisados a partir dos modos como são produzidos, usados, experienciados através de procedimentos, técnicas, estéticas, ideologia, cooperação, negociação e contestação.

14 Ver nota 4. 
A declaração da realização obrigatória de um estudo de impacto ambiental na Terra Indígena Trincheira-Bacajá, os Estudos Complementares do Rio Bacajá, como condição para licenciamento do megaempreendimento hidrelétrico de Belo Monte é resultado da divulgação do Parecer técnico 21 de autoria da Funai (2009). Nesse documento, apesar de concordar com a proposta da Norte Energia para a mudança de grid dos Xikrin de "povos diretamente impactados" para "povos geograficamente mais distantes do empreendimento", a Funai colocou-os na condição de necessitários de realização de um estudo de impacto.

O Parecer técnico 21: análise do componente indígena dos estudos de impacto ambiental UHE Belo Monte é um relatório feito por analistas da Funai que avalia os quadros de indicadores de impacto previstos no estudo de impacto ambiental (EIA).$^{15}$. O parecer da Funai (2009) discorre principalmente acerca da previsão de impactos relacionadas às populações indígenas afetadas. A emissão do parecer permitiu que os trâmites para o licenciamento do empreendimento fossem continuados e proporcionou o início da construção de Belo Monte, indicando a necessidade de realização de algumas condicionantes. A lista das condicionantes ${ }^{16}$ consta no escopo do Parecer técnico 21 , na parte final do documento, e incrementa as ações de mitigações previstas no EIA. A titulação condicionante define tais medidas como condições necessárias a serem realizadas pelo grupo empreendedor para continuidade de licenciamento da obra. A realização dos Estudos Complementares do Rio Bacajá consta como uma delas.

15 EIA e Relatório de Impacto Ambiental (Rima) foram entregues em 2009 ao Instituto Brasileiro de Meio Ambiente e dos Recursos Naturais Renováveis (Ibama). O EIA/Rima de Belo Monte foi elaborado pela Leme Engenharia (2009), afiliada ao Grupo Tractebel Engineering, por sua vez vinculado ao grupo GDF Suez, um dos participantes do leilão para construção da Usina Hidrelétrica de Belo Monte. Em outubro de 2009, cinco meses após a versão final do documento ter sido entregue ao Ibama, chegou ao mesmo órgão, e ao Ministério Público Federal (MPF), um relatório alternativo, de 230 páginas, intitulado Análise crítica do Estudo de Impacto Ambiental do Aproveitamento Hidrelétrico de Belo Monte, elaborado por mais de 40 pesquisadores. Antropólogos, sociólogos, zoólogos, biólogos, etimólogos, doutores em energia e planejamento de sistemas energéticos, historiadores, cientistas políticos, economistas, engenheiros, hidrólogos, ictiólogos, entre outros, compõem um grupo denominado Painel de Especialistas (2009). A empresa responsável pela construção da Usina Hidrelétrica de Belo Monte divulgou outro relatório respondendo às críticas em relação ao empreendimento (cf. Eletrobras et al., 2009).

${ }^{16}$ Ficou estabelecido pela Funai e pelo Ibama um conjunto de 40 condicionantes, que deveriam ser cumpridas para o andamento da obra e liberação da licença prévia e de instalação. Apesar dessa determinação, a licença prévia ambiental foi emitida, em 2010, sem que tais condicionantes tivessem sido cumpridas. Para visualização do quadro das condicionantes, ver Instituto Socioambiental (2013).

Horizontes Antropológicos, Porto Alegre, ano 22, n. 46, p. 159-188, jul./dez. 2016 
Os Xikrin da Terra Indígena Trincheira-Bacajá eram incialmente considerados parte do "Grupo 1: diretamente afetados pela obra". No entanto, segundo avaliações de impacto feitas pelas empresas empreendedoras, os Xikrin deveriam ser deslocados para o "Grupo 2", considerados como parte dos povos que "embora sofram impactos, estão geograficamente mais distantes do empreendimento".

Segundo argumento do grupo de empreendedores, os Xikrin deveriam ser alocados ao "Grupo 2" por dois motivos: primeiro, porque estudos de impacto sobre a hidrologia e condições de navegação do rio Xingu já haviam sido feitos e constavam no EIA; e, segundo, porque o contexto político era desfavorável devido à repercussão negativa do enfrentamento dos Kayapó com um engenheiro da Eletronorte em Altamira em abril de 2008.

A Funai acatou em parte a sugestão do grupo de empreendedores. Se por um lado, concordou com a mudança de grid dos Xikrin do "Grupo 1" para o "Grupo 2", por outro, indicou a necessidade da realização de um estudo de impacto ambiental na Terra Indígena Trincheira-Bacajá, os Estudos Complementares do Rio Bacajá, alegando a necessidade de se estabelecer um quadro de impactos específico para a região da Terra Indígena, que tratasse especialmente da relação hidrológica do rio Bacajá com o rio Xingu. Assim, mesmo compondo o "Grupo 2", os Xikrin deveriam ter, em sua Terra Indígena, a realização de um estudo de impacto ambiental específico, os Estudos Complementares do Rio Bacajá.

UHE Belo Monte - Componente Indigena

Parecer técnico nº 21/CMAM/CGPIMA-FUNAI

Retomamos também a questào do estudo do Rio Bacajá. A justificativa para o deslocamento da TI Trincheira Bacajá do Grupo 01 para o Grupo 02 se pautou na perspectiva de que o estudo da TI Arara da Volta Grande, bem como do meio físico, responderiam as questões pertinentes ao Rio Bacajá e à navegabilidade dos Xikrin até a cidade de Altamira. No entanto, após a análise prévia dos estudos entregues, essa abordagem se mostrou insuficiente. pois foi apontada a forte dependência dos Xikrin nesse rio. Há, portanto, necessidade de estudos complementares sobre os aspectos de navegabilidade, ictiofauna, sedimentação e hidrologia.

Figura 1. Trecho extraído do documento Parecer técnico 2l (Funai, 2009, p. 68). 
A necessidade de realização de um estudo de impacto ambiental na Terra Indígena Trincheira-Bacajá também era defendida pelos Xikrin, que participaram de reuniões em Altamira com a Funai e representantes da Norte Energia para garantir que os estudos se realizassem. Segundo eles, "é preciso fazer estudos no rio Bacajá, porque nenhum branco conhece esse rio direito e porque com o secamento de parte do Xingu, o rio Bacajá pode desaparecer".

Nós falamos para o pessoal da Funai e da Norte Energia que o impacto ia ser também aqui com nossas aldeias e com a vida dos nossos filhos, e netos. Antes ninguém queria aceitar isso e de tanto a gente falar e falar nas reuniões, a Funai teve que aceitar. Se não fosse isso, da gente falar, não ia ter estudo aqui no nosso rio Bacajá. (Cabokinho, segundo cacique da aldeia Bacajá, comunicação pessoal, 2011).

Além disso, as preocupações dos Xikrin voltavam-se para as datas do cronograma de construção da obra e o cumprimento das condicionantes pelo empreendedor, visto que os Estudos Complementares do Rio Bacajá só foram iniciados em 2011, dois anos depois da emissão do Parecer técnico 21, enquanto a usina de Belo Monte já estava em fase adiantada de construção.

A barragem começou antes de terminar os nossos estudos aqui. Isso não é certo, não. Ninguém fez as coisas aqui para nós, na aldeia, ninguém fez nada. A Norte Energia tinha que fazer as coisas antes. Do jeito que está fazendo, não está certo e a gente não aceita isso. Não fizeram o posto de vigilância e ninguém falou para gente quando vai fazer. A gente não quer kubẽ [branco] aqui na nossa área, pescando aqui e caçando. (Tedjêre, cacique antigo, aldeia Mrotidjam, comunicação pessoal, 2011).

A garantia da realização dos Estudos Complementares do Rio Bacajá foi uma demanda dos Xikrin que queriam, através desses estudos, mostrar para os kubẽ do ngô beyêt (brancos de Belo Monte) o conhecimento que eles tinham do rio Bacajá e da relação deste com o rio Xingu. A intenção dos Xikrin era ensinar/mostrar/falar que seus conhecimentos (kukràdjà) deveriam ser considerados pelos engenheiros e por todos envolvidos com a obra. Queriam mostrar que seus conhecimentos eram bons, corretos, verdadeiros (kukràdjà mejxtere). Queriam que os engenheiros ouvissem seus conhecimentos para aprenderem sobre o rio Bacajá e sobre a relação desse rio com o rio Xingu. Queriam "mostrar kukràdjà para os kubẽ".

Horizontes Antropológicos, Porto Alegre, ano 22, n. 46, p. 159-188, jul./dez. 2016 
Nesse sentido, o Parecer técnico 21 associa-se ao classificador kaigo (falso/fajuto) porque, se, por um lado, garantiu a realização de um laudo de impacto ambiental na Terra Indígena Trincheira-Bacajá, por outro, manteve os Xikrin como "Grupo 2: povos impactados, mas geograficamente mais distantes da obra". Os Xikrin queriam a realização dos estudos em sua Terra Indígena, mas se consideravam como "diretamente impactados" e não se consideram "geograficamente distantes de Belo Monte", porque os seus "avós e parentes caminhavam por toda aquela região onde a usina está sendo construída, por conhecerem a região, por viverem ali antes dos kubẽ (brancos) saberem que aquela região existia".

A demanda dos Xikrin pela realização dos Estudos Complementares do Rio Bacajá foi atendida, apesar da mudança de grid em que foram deslocados do grupo de "povos diretamente afetados". Porém, as expectativas que eles tinham com os resultados dos estudos não se consolidaram, como será apresentado na quarta parte deste artigo. Na próxima sessão, associada ao classificador mejx/mejxtere (bom, belo correto), será discutida as formas de coleta de dados das equipes, contratadas para realização dos Estudos Complementares do Rio Bacajá, em paralelo com o modo como os Xikrin apresentavam/mostravam/narravam seus conhecimentos (kukràdjà).

\section{Equipe de pesquisadores nas aldeias: mejx/mejxtere (belo/correto/verdadeiro). Engajamento xikrin em mostrar kukràdjà (conhecimento/cultura)}

O trabalho das equipes em campo para "coleta de dados" durante a realização dos Estudos Complementares do Rio Bacajá é associado ao classificador mejx/mejxtere (belo/correto/verdadeiro) por conta do engajamento dos Xikrin nas atividades propostas e por seus esforços em mostrar/ensinar seus conhecimentos (kukradjà) aos pesquisadores das equipes em campo.

Minha participação entre as equipes de pesquisadores contratados para coletar dados entre os Xikrin deu início à minha pesquisa de doutorado. ${ }^{17}$ Posteriormente aos Estudos Complementares do Rio Bacajá, acompanhei, junto com os Xikrin, a ocupação de Belo Monte entre julho e agosto de 2012.

17 Minha participação no processo de coleta de dados para a elaboração dos Estudos Complementares do Rio Bacajá decorre de um pedido dos Xikrin à Clarice Cohn que acompanhasse as atividades de formulação do laudo e que enviasse alguém de sua confiança para trabalhar junto com os técnicos em campo. 
Realizei ainda mais dois períodos de trabalho de campo, somando mais seis meses em 2013 e outros seis entre 2014 e 2015.

A maioria dos pesquisadores contratados pela Leme Engenharia ${ }^{18}$ para realização dos Estudos Complementares do Rio Bacajá eram biólogos vinculados a cursos de graduação e pós-graduação de universidades brasileiras. As equipes foram divididas, de acordo com a especialidade dos pesquisadores, em três grupos: ictiofauna e consumo alimentar; navegação; e qualidade da água. Cada viagem das equipes à Terra Indígena Trincheira-Bacajá era chamada pelos coordenadores dos estudos de "campanhas" e um calendário foi estabelecido para que as equipes estivessem em períodos diferentes umas das outras nas aldeias. Assim, ao longo do ano de 2011, as aldeias xikrin receberam visitas continuadas das equipes. Cada "campanha" obedecia ainda ao ciclo hidrológico dos rios Bacajá e Xingu: cheia, vazante, seca e enchente.

O desenvolvimento do trabalho das equipes em campo pode ser descrito pela disposição de engajamento dos Xikrin nas atividades propostas pelos pesquisadores. A cada "campanha", assim que as equipes chegavam às aldeias, era organizada uma reunião no ngàb (casa do meio/casa do guerreiro), no centro da aldeia, para definição das atividades a serem realizadas.

Além das atividades consideradas pelos biólogos em campo como "mais objetivas", como era o caso da pesagem das espécies de peixes e caça consumidas, fotografias das espécies coletadas e retirada de amostras para análise de mercúrio; também eram realizadas atividades "etno" como conversas sobre os peixes e animais de caça, confecção de mapas sobre os ciclos hidrológicos do rio, calendários sazonais de produção agrícola e notações sobre previsões de impacto feitas pelos Xikrin. Era bastante comum que fosse utilizado nas atividades "etno" algum mapa georreferenciado de toda a área indígena com os limites de usos entre cada aldeia, da forma como havia sido marcado nos pontos com uso de GPS, durante a "campanha" anterior. ${ }^{19}$

Os Xikrin mostravam nos mapas os principais pontos de pesca que utilizavam em cada um dos ciclos hidrológicos: locais de maior presença de

18 Trata-se de uma empresa de engenharia com atuação na América Latina, que no Brasil, é representante do grupo Tractebel Engineering (GDF Suez). A empresa foi contratada pela Norte Energia para a execução dos estudos de impacto ambiental para a região da Volta Grande e Altamira, e posteriormente para realização dos Estudos Complementares do Rio Bacajá.

19 Mesmo na primeira campanha, foram levados mapas georreferenciados com alguns pontos já indicados que resultaram de um encontro dos Xikrin com Clarice Cohn e Isabelle Giannini em 2009.

Horizontes Antropológicos, Porto Alegre, ano 22, n. 46, p. 159-188, jul./dez. 2016 
tracajás, ${ }^{20}$ chamados boiadores; os locais de difícil navegação, devido às cachoeiras; as regiões na mata com maior concentração de açaí e castanha; os locais de barreiros, onde são mais comumente encontrados os porcões ${ }^{21}$ do mato; as aldeias antigas; roças antigas e já abandonadas; roças em uso; presença de frutas e palmitos comestíveis; locais onde se encontram jenipapo. ${ }^{22}$ Os pesquisadores anotavam as informações e faziam marcações nos mapas, filmavam e fotografavam essas atividades, gravavam as falas dos velhos sobre uma história relacionada a um local específico ou sobre como eles encontraram outros grupos indígenas naquelas regiões. Os mais velhos narravam histórias sobre localidades importantes da Terra Indígena, contavam sobre caçadas bem-sucedidas e fracassadas, enquanto os mais jovens traduziam as falas dos velhos e mostravam-nos como grafar os nomes das localidades mebêngôkre. ${ }^{23}$ Entre a grafia de um nome e outro, os Xikrin insistiam para que os membros das equipes repetissem os nomes até a pronúncia ficar correta (mebêngôkre kaben mejxtere). Os Xikrin estavam compartilhando seus conhecimentos, ensinando/mostrando kukràdjà (cultura) às equipes de pesquisadores.

Essa parte aqui do mato [apontando para o mapa] tem nome Irepopare. Quando era criança, Ireporare sumiu nesse mato e se perdeu. Ela ficou três dias

20 Tipo de tartaruga de água doce, da família dos pelomedusídeos (Podocnemis unifilis), encontrada nos rios amazônicos, com cerca de $50 \mathrm{~cm}$ de comprimento, carapaça abaulada, pardo-escura, e cabeça com manchas alaranjadas. Os Xikrin chamam-na kapran krantoe, consomem sua carne, preferencialmente assada, e seus ovos, que são encontrados nas praias do rio Bacajá, especialmente em setembro, época de desova do animal e vazão do rio.

${ }^{21}$ Dois tipos de porcões são mais recorrentes na Terra Indígena dos Xikrin. Um de tamanho menor com uma faixa clara ao redor do pescoço, que os Xikrin chamam angrore, regionalmente chamado de catitu que é um mamífero também chamado de porco-do-mato ou cateto (Tayassu tajacu), artiodátilo da família dos taiaçuídeos de hábitos diurno e ambiente florestal, com cerca de $90 \mathrm{~cm}$ de comprimento e pelagem cinza-escura com uma faixa branca no pescoço, em forma de colar. E outro de tamanho maior, chamado pelos Xikrin de angrô, e regionalmente, porco-do-mato, um mamífero artiodátilo (Tayassu pecari) da família dos taiaçuídeos, diurno e terrestre, com cerca de $1 \mathrm{~m}$ de comprimento e pelagem negra com o queixo branco; que vive em bandos com até 300 indivíduos.

${ }^{22}$ Fruto do jenipapeiro (Genipa americana) geralmente amarelo-pardacento, com polpa aromática e comestível. Os Xikrin chamam o jenipapo de mroti, e seu uso está relacionado com a aplicação da pintura corporal. As mulheres cortam o fruto ao meio, extraem sua parte interna com as sementes, mastigam e cospem a massa numa cuia onde será misturada com carvão e depois aplicada no corpo. Sobre técnicas de pinturas corporais xikrin, ver Vidal (2000).

${ }^{23}$ Os Xikrin possuem atualmente em suas aldeias escolas que oferecem formação até o $5^{\circ}$ ano do nível Fundamental II. Alguns jovens da aldeia aprenderam a escrever sua língua num intercâmbio à cidade de São Félix do Xingu (PA), onde ocorre tal alfabetização através da atuação de um grupo de missionários evangélicos.

Horizontes Antropológicos, Porto Alegre, ano 22, n. 46, p. 159-188, jul./dez. 2016 
desaparecida. Os homens ficavam procurando por ela com o barco e nada. Sua mãe e sua avó já estavam chorando, pensando que ela tivesse morrido. No terceiro dia, quando os homens estavam navegando para procurá-la, ouviram gritos de chamado do outro lado da margem. Irepopare estava lá. Estava magra e confusa. Colocaram-na no barco e a trouxeram de volta para a aldeia. Por isso demos o nome dela para o mato onde ela se perdeu e todos conhecem esse nome e essa história. (Prunkey, guerreiro antigo, aldeia Pot-Krô, comunicação pessoal, 2011).

Além das atividades "etno" nas aldeias, as equipes organizavam com os Xikrin expedições de pesca e visitas a pontos de caça, coleta, roças e locais de aldeias velhas. Durante os trajetos, os Xikrin explicavam detalhes sobre os canais de navegação do rio Bacajá, levavam os pesquisadores aos pontos de pesca mais usados em cada ciclo hidrológico do rio, diziam quais espécies de peixe eram mais comuns e os mais consumidos em cada um desses ciclos, levavam os pesquisadores a incursões na mata para mostrarem locais de barreiros e açaizais. Ao final do dia, no ngàb (casa do meio), os Xikrin contavam mais histórias e pediam para que os pesquisadores registrassem essas falas.

Os mais antigos viviam andando, moravam ali onde hoje é lugar de fazendeiro, antes nossos avós moravam andando. Andavam até o igarapé But Pramei e o Moptu, pegavam o jenipapo para as mulheres fazerem as pinturas. Chegavam até o igarapé Ikiebepuro, hoje tem uma cidadezinha lá. Andavam tudo até descer para o Xingu. Andava pela pedra do índio, tudinho. Aqui no mato não tinha kubẽ, kubẽ tinha medo do índio. Kubẽ ficava só em Altamira e o índio pegava tudo do kubẽ: espingarda, facão, machado. Antes andava até a TI Apyterewa e Koatinemo, onde os Parakanã e os Assurini moram. Andava até o igarapé Tucunaré, nosso avô andava lá por cima do igarapé Goiaba onde tem vila hoje. Atravessa o rio a pé, amarrado no cipó, não tinha canoa não. Hoje o índio come óleo, sal, açúcar e morre. Antigamente todo mundo ficava bem velho, velhinho mesmo e não morria. Antes o pessoal novo quebrava castanha para trazer para o pessoal velho e depois comia e banhava e dançava. Isso é a cultura e pode acabar por causa da barragem. Antes, só pegava peixe no cipó ou na flecha e ficava no mato para comer castanha, palmito, babaçu, bacaba, açaí. A panela para carregar água era a taboca de bambu. (Bep Djeti, cacique antigo, aldeia Bacajá, comunicação pessoal, 2011).

As crianças, os jovens e os adultos faziam desenhos e mapas da aldeia, das roças, da Terra Indígena, dos animais de caça, dos peixes. 


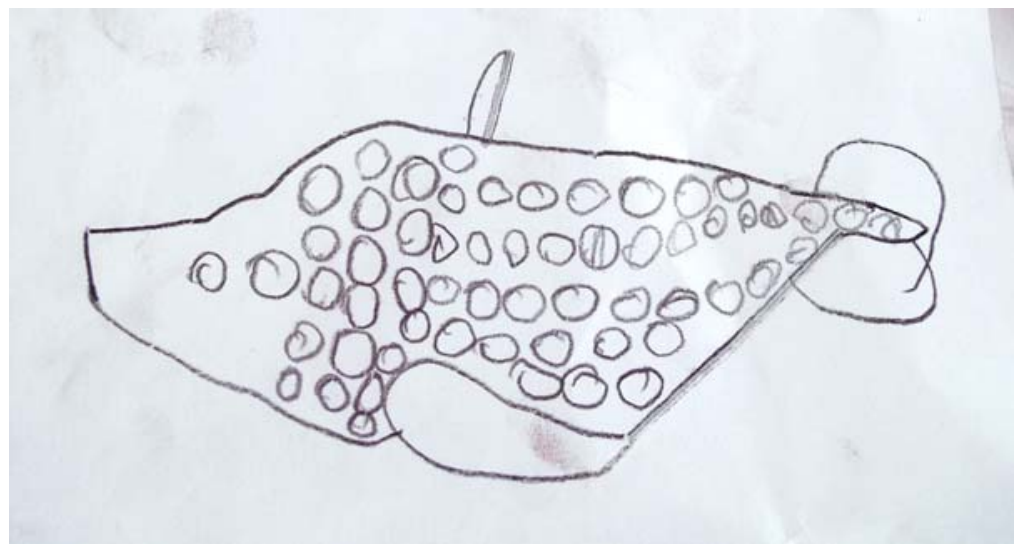

Figura 2. Desenho feito por criança durante oficina de uma das atividades "etno" (acervo pessoal, aldeia Pot-Krô, 2011).

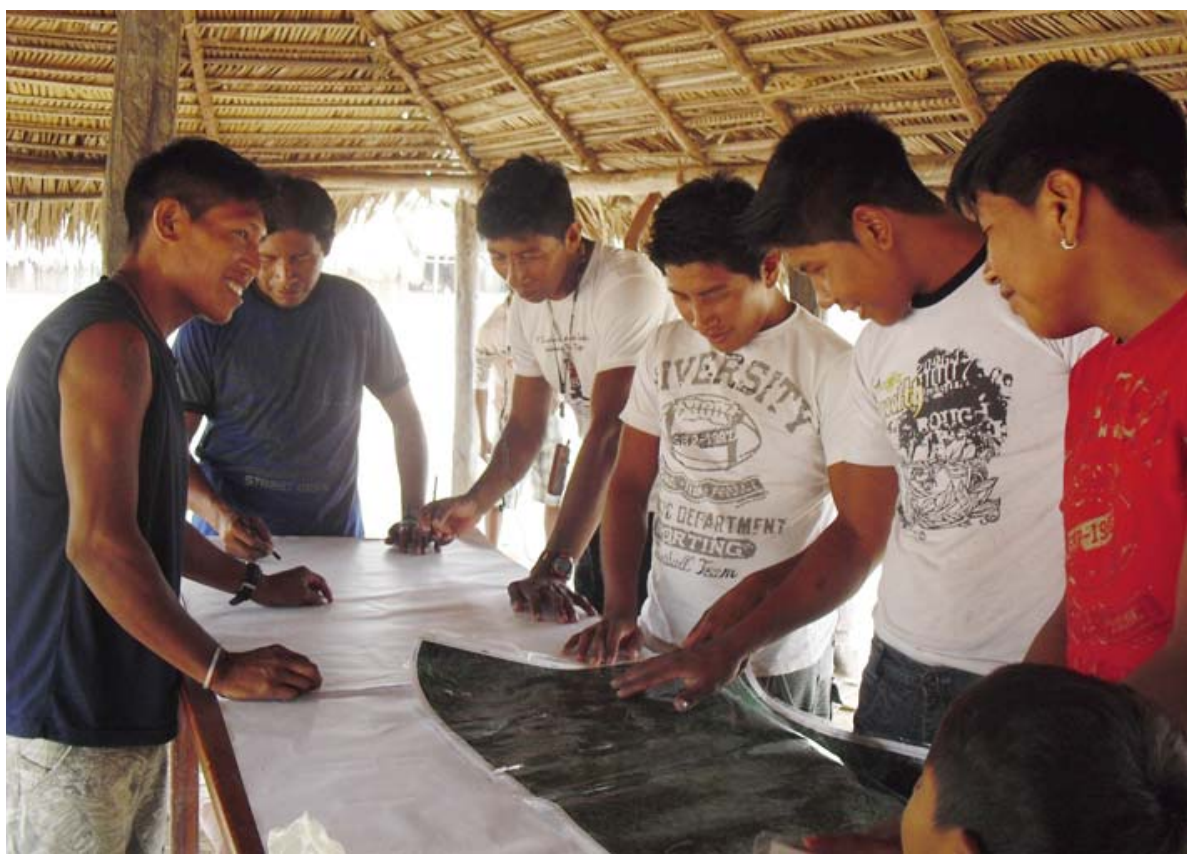

Figura 3. Registro fotográfico de atividade para desenho e mapeamento da aldeia (acervo pessoal, aldeia Bacajá, 2011). 
Ao pedirem os registros das falas, os Xikrin desejavam que seus conhecimentos sobre o rio Bacajá, a relação hidrológica deste com o rio Xingu, suas formas de manejo e uso dos recursos naturais fossem divulgados no documento dos Estudos Complementares do Rio Bacajá. Estavam operando um procedimento de legitimação/divulgação de seus conhecimentos e saberes para os kubẽ (brancos) envolvidos com a construção de Belo Monte.

Muitas vezes usando gravetos que eram riscados no chão de terra, os mais velhos explicavam a relação do rio Bacajá com o Xingu e os mais jovens traduziam essas falas para os técnicos em campo:

O rio Bacajá é pequeno e corre muito, tem muitas cachoeiras. É o rio Xingu que segura o rio Bacajá. Na época da seca, quando o rio Xingu seca, o rio Bacajá desce todo, vai embora também porque não fica mais nada lá para segurá-lo. Quando o rio Xingu está cheio, o rio Bacajá fica cheio também, porque não consegue vazar, não desce e não vai embora. Se tiver barragem, o rio Xingu vai ficar seco e nada mais vai segurar o rio Bacajá. Se tiver barragem o rio Bacajá irá todo embora, vai vazar até acabar.

Em muitas ocasiões, os Xikrin apresentavam suas previsões de impacto.

Se o Xingu secar, o Bacajá vai secar também. E se o Bacajá secar, a caça vai embora para longe, os peixes vão morrer porque muitos deles saem do Xingu e sobem para o Bacajá, os tracajás vão morrer porque a água do Bacajá vai ficar quente, o rio vai ficar raso e com muita corredeira. Não conseguiremos mais navegar. Como vai ser para nossos filhos e netos? Eles vão viver de quê? Porque só sobrarão ratos e sapos. E nossos filhos e netos terão de comer sapos e ratos?

Se os Xikrin queriam mostrar seus conhecimentos para os brancos envolvidos com a construção de Belo Monte, a intenção dos pesquisadores era coletar as informações e padronizá-las, preferencialmente em gráficos, para as tornarem "dados". Os Xikrin operavam no compartilhamento/divulgação de seus conhecimentos, enquanto as equipes coletavam dados. A diferença dessas intenções pode ser associada ao conceito de equivocação (Viveiros de Castro, 2004) ${ }^{24}$ e tomadas como expressões de encontros

24 Argumento desenvolvido por Viveiros de Castro (2004) sobre como operar em antropologia processos de tradução e comparação. Segundo o autor, é apenas tomando a própria antropologia como perspectiva (perspectival), ou seja, como uma formação híbrida que resulta da imbricação entre discursos

Horizontes Antropológicos, Porto Alegre, ano 22, n. 46, p. 159-188, jul./dez. 2016 


\author{
pragmáticos (Almeida, 2013)..$^{25}$ \\ Mesmo com intenções diferentes, Xikrin e pesquisadores engajavam-se ${ }^{26}$ \\ nas atividades "etno" e nas "mais objetivas" que compunham a metodologia \\ de trabalho das equipes nas aldeias para coleta de dados a serem utilizadas, \\ posteriormente, na redação dos Estudos Complementares do Rio Bacajá.
}

antropológicos ocidentais e imagens conceituais transportadas pela cosmopráxis ameríndia, fundamentada pela teoria perspectivista, unicultural e multinatural, que o processo de boas traduções pode ser realizado. Com intenção de responder à questão: "como podemos restaurar as analogias traçadas pelos índios amazônicos dentro dos termos de nossas próprias analogias?" (Viveiros de Castro, 2004, p. 4), o autor propõe a noção de equivocação como um sentido para reconceituar, com a ajuda da antropologia perspectivista ameríndia, a comparação enquanto procedimento emblemático da disciplina. Trata-se de uma comparação que não é implícita ou automática (ou descontrolada), mas que inclui o discurso antropológico como um de seus termos. Uma boa tradução antropológica é aquela que segue conceitos estrangeiros para deformar e subverter a caixa de instrumentos conceituais próprias do tradutor, de modo que o inventismo da linguagem original possa ser expresso dentro de outra linguagem (a antropológica). Em suas palavras: "[...] alego que o perspectivismo projeta uma imagem de tradução como um processo de equivocação controlada - controlada no sentido em que uma curta caminhada possa ser considerada como uma forma controlada de queda. Perspectivismo indígena é uma teoria da equivocação, qual seja, de uma alteridade referencial entre conceitos homônimos. Equivocação aparece aqui como um modo de comunicação por excelência entre diferentes posições perspectivas - e, portanto, tanto como condição de possibilidade e de limite da inciativa antropológica" (Viveiros de Castro, 2004, p. 5).

${ }^{25}$ Conceito desenvolvido por Almeida (2013) que propõe uma reflexão sobre o reconhecimento do conflito entre ontologias, bem como algumas áreas de possíveis acordos entre elas. A sugestão do autor de tomar metodologicamente a proposta de "encontros pragmáticos" opera como uma alternativa ao modelo da tradução que desconsidera a existência concomitante de ontologias múltiplas que podem ser incompatíveis entre si. Esse procedimento só é possível se as verdades forem tomadas como "parciais" ou "pragmáticas", ou seja, não traduzíveis num esquema de totalização prévio ou de suposições modelares de existências e relações causais. Encontros pragmáticos implicam a simetrização das convicções dos ribeirinhos do Alto Juruá sobre a ação de seres encantados do fundo do rio e nas matas, "ontologia caipora", e dos modelos analíticos dos técnicos para manejo florestal. As ontologias científicas não devem ser consideradas como índices mais verdadeiros da realidade porque tal convicção e arrogância destrói a possibilidade dos encontros pragmáticos. Se tomadas como verdade, as ontologias científicas ou de mercado destroem a "ontologia caipora" e extermina as possibilidades de diferenças e multiplicidade ontológicas. Não considerar simetricamente a "ontologia caipora" é colocar em jogo a existência de entes no sentido pragmático, "é uma questão de vida e de morte para Caipora, para antas e macacos, para 'gente-de-verdade' e para pedras e rios" (Almeida, 2013, p. 22). Ignorar a multiplicidade de ontologias por meio dos encontros pragmáticos é bloquear o surgimento incessante de novos entes materiais e imateriais, visíveis e invisíveis, humanos e não humanos. A luta por reconhecimento é a luta por existência, uma luta por multiplicação de ontologias.

${ }^{26}$ O conceito de engajamento que utilizo aqui se inspira nos trabalhos de Donna Haraway $(1988,2008)$, cuja formulação refere-se às interações e intenções de interações entre humanos e entre humanos e outras espécies, de forma que toda aliança estabelecida é precária e nunca está plenamente assegurada. Etnografias recentes têm expandido a noção de engajamento, como é o caso, por exemplo, de Tsing (2005) sobre os meratus dayak da região das montanhas Kalimantan, Indonésia e projetos ambientalistas; Kohn (2002) sobre os quéchuas (ávila runa) da Amazônia Equatoriana e suas formas de engajamento com espécies animais de caça e com seus cachorros; Willerslev (2007) sobre os yukaghirs da Sibéria e a presa em uma caça que é vista como uma amante que precisa entregar-se ao caçador, num jogo de sedução.

Horizontes Antropológicos, Porto Alegre, ano 22, n. 46, p. 159-188, jul./dez. 2016 
A insatisfação dos Xikrin com os Estudos Complementares do Rio Bacajá não ocorreu durante as atividades das equipes nas aldeias, mas sim na apresentação da versão final de redação dos estudos, quando perceberam que seus conhecimentos não estavam contemplados no documento. É dessa insatisfação com a versão final dos estudos que trato a seguir.

\section{Versão final dos Estudos Complementares do Rio Bacajá: documento punú/ punure (feio/incorreto)}

Os Estudos Complementares do Rio Bacajá foram apresentados aos Xikrin em março e abril de 2012. Essas apresentações contaram com a participação de engenheiros responsáveis pela coordenação dos estudos, um representante da Norte Energia, dois especialistas que integraram as equipes de coleta de dados, um servidor temporário da Funai de Altamira ${ }^{27}$ e eu, na função de "acompanhamento antropológico". Nessas apresentações, realizadas nas cinco aldeias contempladas pelos estudos, os engenheiros utilizaram folders contendo as principais informações de cada um dos tópicos avaliados: ictiofauna e consumo alimentar, navegação, qualidade da água.

As apresentações da versão final dos Estudos Complementares do Rio Bacajá geraram muitos desentendimentos entre os Xikrin e os engenheiros. Isso porque os Xikrin perceberam que suas teorias sobre o rio Bacajá, a relação deste com o rio Xingu e suas previsões de impacto, não estavam contempladas no documento, da forma como eles desejavam que estivessem. Os conhecimentos (kukràdjà) que os Xikrin mostraram aos pesquisadores das equipes haviam se transformado em gráficos matemáticos de vazão do rio. Além disso, toda a teoria dos Xikrin sobre a relação do rio Bacajá com o rio Xingu não estava presente no documento e era questionada pelos engenheiros.

$\mathrm{Se}$, ao longo das atividades das equipes em campo, a grande maioria das considerações, feitas pelos Xikrin, eram tratadas, pelos técnicos, como

\footnotetext{
${ }^{27} \mathrm{O}$ fortalecimento da Funai em Altamira era um das ações de condicionantes a serem cumpridas pela Norte Energia. Em 2011 foram contratos alguns servidores temporários que após um ou dois anos de trabalho foram dispensados sem serem incorporados pela instituição. Agradeço aqui a Rosamaria Lourdes que acompanhou comigo as reuniões nas aldeias da Terra Indígena Trincheira-Bacajá para apresentação dos resultados dos estudos. Sua presença foi fundamental para o processo de registro das críticas feitas pelos Xikrin aos engenheiros, de forma que sua dedicação e amizade tornaram-se admiradas e reconhecidas pelos Xikrin e por mim.
}

Horizontes Antropológicos, Porto Alegre, ano 22, n. 46, p. 159-188, jul./dez. 2016 
informações importantes, tendo sido anotadas e gravadas por vários deles, a forma de apresentação dessas informações na versão final dos Estudos Complementares do Rio Bacajá, elaborado por coordenação da Leme Engenharia, assume outra forma. Tal forma implicou a codificação de informações descritivas em dados numéricos para geração de gráficos e tabelas. A codificação realizada para confecção do documento final dos estudos desembocou num efeito de obliteração das falas dos Xikrin. Trechos mais descritivos enviados pelos pesquisadores transformaram-se em números de gráficos que os Xikrin consideraram punure (obscuros, incorretos, não verdadeiros).

Os Xikrin questionaram os engenheiros durante as apresentações da versão final dos estudos, querendo saber onde estavam todas as narrativas feitas aos pesquisadores, os mapas que desenharam apontando para atividade madeireira e previsão de aumento do risco de invasão na Terra Indígena, as histórias de cada lugar de caça e pesca, das cachoeiras mais perigosas do rio, de como os mais velhos andavam por toda a área antes do contato com o branco e, principalmente, da relação entre o rio Bacajá e o rio Xingu que eles haviam explicado para os pesquisadores. A resposta convencional dos engenheiros da Leme Engenharia, que apresentavam os resultados dos estudos, era a de que seria impossível que o documento contivesse todas as informações colhidas, porque se assim o fizesse, o tamanho do documento seria impraticável.

O principal ponto de desacordo entre os engenheiros que apresentavam os estudos e os Xikrin recaiu sobre a relação hidrológica do rio Bacajá com o rio Xingu e as previsões de impacto para o rio Bacajá com o barramento do rio Xingu, decorrente da construção da hidrelétrica de Belo Monte.

Os engenheiros apresentaram gráficos para defenderem suas teorias e tentavam explicá-los aos Xikrin. Segundo os engenheiros, o impacto do barramento do rio Xingu para o rio Bacajá não será significativo, porque a área de influência do rio Xingu no rio Bacajá só atinge até uma determinada região, a cachoeira Percata, que se localiza antes da demarcação da Terra Indígena Trincheira-Bacajá, ou seja, fora da Terra Indígena. Por esse motivo, segundo os engenheiros, o rio Bacajá não sofrerá "impactos significativos" com o barramento do rio Xingu, decorrente de Belo Monte. De forma que, segundo os engenheiros:

A vida de vocês, Xikrin, aqui na Terra Indígena não será alterada significativamente com a construção do empreendimento porque os regimes de cheia, seca, 
vazante e enchente do rio Bacajá permanecerão muito próximos do que ocorre hoje sem a barragem.

Para defender suas teorias, os engenheiros apresentaram alguns gráficos, dentre eles:

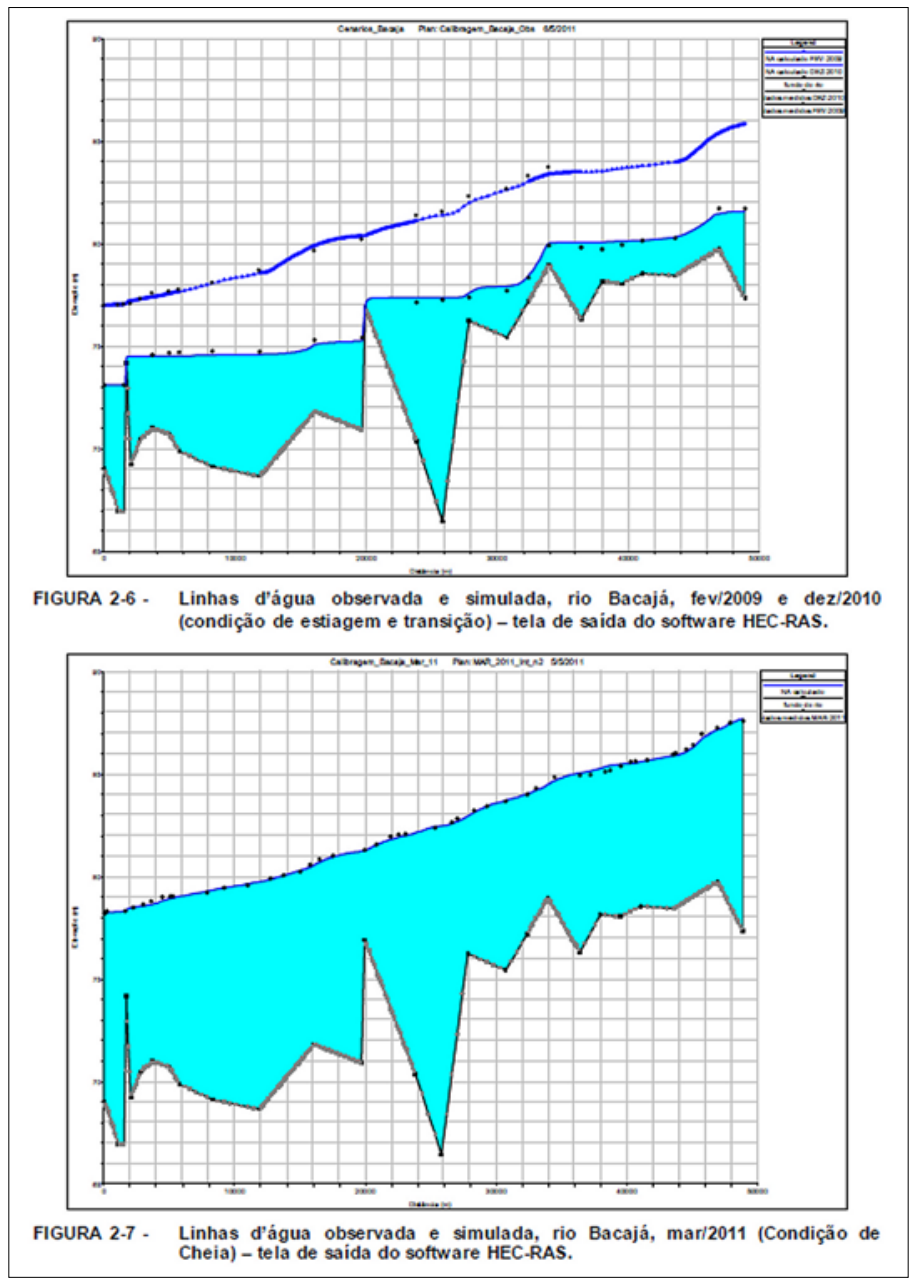

Figura 4. Gráfico extraído do laudo dos Estudos Complementares do Rio Bacajá usado nas reuniões de apresentacão dos resultados nas aldeias em formato de folder. 
Ao ser apresentado a esses gráficos, Meiti, uma liderança velha (benadjuro tüm), levantou-se e falou de forma dura (kaben toxj) com o engenheiro apontando para ele sua flecha esticada no arco, como se fosse flechá-lo. Depois que a liderança velha terminou de falar, o cacique realizou a tradução:

Vocês estão falando mentira, falando errado, não sabem nada do rio Bacajá, nem do rio Xingu. Vocês nem moram aqui e por isso não sabem como tudo funciona. Vocês não podem vir na aldeia falar mentira para nós. Vocês querem enganar nosso povo, sempre foi assim. Os Xikrin sabem como vive o rio Bacajá e como vive o rio Xingu. Os Xikrin sabem tudo aqui e nós contamos para vocês, pedimos para escreverem no papel, para gravarem no gravador, para vocês aprenderem e para vocês escreverem um documento verdadeiro, correto, bonito. Eu sei que o rio Bacajá vai secar, todos os Xikrin sabem, mas vocês não querem acreditar. Eu vou falar reto para você, falar direto, porque Mẽbêngôkre fala assim forte e reto, não enrola ninguém. Quero apostar com você. Se vocês estiverem certos e o rio Bacajá não secar com o barramento do Xingu, vocês voltarão aqui na aldeia e poderão me amarrar num pau no meio da aldeia onde eu ficarei amarrado três dias e três noites, sem comer e nem beber água. Agora, se vocês estiverem errados e o rio Bacajá secar, ficar quente e rápido eu vou te buscar e vou te amarrar aqui na aldeia por três dias e três noites, sem água e sem comida. Vocês precisam aprender que os Xikrin conhecem o rio Bacajá e sabem que ele vai secar se o rio Xingu for barrado. Os Xikrin falam certo e vocês falam feio, falam mentira.

Cada uma das lideranças velhas (benadjuro tüm) expressou seu descontentamento com as falas dos engenheiros. Seguindo uma etiqueta de fala mẽbengôkre, em que os chefes antigos falam primeiro, depois os chefes atuais, depois os guerreiros com netos e posteriormente os guerreiros mais jovens, cada um expressava seu descontentamento com a apresentação do resultado dos Estudos Complementares do Rio Bacajá.

Vocês são kubẽ. Ninguém de vocês mora aqui na aldeia. Vocês não conhecem nada, não sabem nada. $E$ vocês querem vir aqui na nossa aldeia para dizer que nós não conhecemos nosso rio, nosso mato. Querem vir aqui para dizer que a gente não sabe nada, que o índio não serve para nada. Não pode desse jeito. Nossos parentes estavam aqui desde sempre por essa região. Vocês, não. Eu era menino quando apareceu o primeiro kubẽ. Antes não tinha kubẽ. Por isso eu falo. A gente, os índios mẽbêngôkre, a gente sabe que o rio vai secar e o peixe vai morrer, vai ter muita malária aqui e todo mundo vai ficar doente. Mas para vocês isso não importa. (Karangré, cacique antigo da aldeia Mrotidjam, comunicação pessoal, 2011).

Horizontes Antropológicos, Porto Alegre, ano 22, n. 46, p. 159-188, jul./dez. 2016 
Além de discordarem da hipótese dos engenheiros de que o rio Bacajá "não secará de forma significativa após o barramento do rio Xingu", os Xikrin alertavam para uma relação hidrológica cujo ciclo de cheia e seca tem aproximadamente dez anos de intervalo. Segundo os Xikrin, a cada período de dez anos (aproximadamente) os rios Bacajá e Xingu vivenciam uma seca bastante severa e mais duradoura. Por esse motivo, afirmavam que um ano de realização de estudos não era suficiente para que os engenheiros entendessem e vissem esse período de seca.

Vocês não estão acreditando no que nós estamos falando. Os velhos sabem que houve uma seca aqui muito brava, faz uns dez anos e muito peixe morreu, a água engrossou e esquentou muito, não dava para beber. Estamos dizendo que um ano de estudo é pouco porque ninguém nunca estudou antes esse rio. Não dá para definir só com esse estudo pequeno os impactos da usina. (Bebeto, liderança da aldeia Pot-Krô, reunião de apresentação dos Resultados dos Estudos, 2011).

A versão final dos Estudos Complementares do Rio Bacajá apresentada aos Xikrin não lhes agradou. Frente a esse impasse, os Xikrin decidiram que suas teorias sobre o rio Bacajá e Xingu, bem como suas previsões de impactos, deveriam estar presentes no documento. Jovens e velhos uniram-se para redação de um documento que explicasse suas teorias, seus saberes.

Ficou decido que as falas de todos os Xikrin deveriam estar contidas nesse documento. Assim, ouvimos as gravações das reuniões com os engenheiros em que os Xikrin questionavam os dados apresentados na versão final dos estudos para transcrevê-las no papel e entregar para os representantes da Leme Engenharia e da Norte Energia, que acompanhavam a apresentação dos estudos.

Os trechos de falas priorizados pelos Xikrin para serem transcritos relacionavam-se com seus conhecimentos sobre o rio Bacajá e suas previsões de impacto.

Vocês não entendem isso. $\mathrm{O}$ rio precisa encher para os peixes subirem e ir desovar nos igarapés. Se o rio ficar muito raso e com muita cachoeira o peixe vai sumir. Já hoje, onde o rio corre mais os peixes somem, vocês viram isso, nós mostramos para vocês. (Koka, guerreiro jovem, aldeia Mrotidjam, 2011).

O documento produzido nas aldeias onde ocorria a apresentação dos Estudos Complementares do Rio Bacajá foi entregue em formato digitalizado em um pen drive para os engenheiros responsáveis dos estudos. Os engenheiros 
explicaram que tal documento só poderia fazer parte da versão redigida dos estudos em formato de anexo. Os Xikrin não se sentiram satisfeitos ao saberem que, como anexo, seus documentos ficariam na parte final dos estudos.

Kukràdjà dos Xikrin Mẽbêngôkre não é uma coisa pequena. É algo muito forte e muito bonito, não deveria estar só no final do documento. Porque nós Xikrin Mẽbêngôkre sabemos muito sobre nosso rio Bacajá, nós queremos que vocês aprendam isso, por isso contamos muito para vocês, falamos muito. Nosso documento, que vem do nosso kukràdjà, é muito mais verdadeiro e muito mais bonito que esse estudo que vocês mostraram para gente.

Se, por um lado, as atividades das equipes dos estudos em campo eram fundamentadas pelas colaborações dos Xikrin; por outro, o produto final gerado apagou tais colaborações em nome da unidade, do modelo do documento enquanto artefato, para remeter a um debate de Riles $(2001,2006)$. A estética do modelo dos Estudos Complementares do Rio Bacajá acabou por obliterar o posicionamento dos Xikrin, suas expressões acerca dos seus conhecimentos dos rios Bacajá e Xingu e suas previsões de impacto em favor de análises numéricas e medições matemáticas de vazão do rio Bacajá.

A crítica dos Xikrin ao formato final dos Estudos Complementares do Rio Bacajá reforça o argumento de Riles (2001) acerca do procedimento de produção de certos tipos de documentos que atua num eclipsamento mútuo de onde surge um modelo de (re)conhecimento singular. Segundo a autora, a habilidade do exercício dos que redigem os documentos reside em certos detalhes, em degraus de familiaridade com a convenção estética, que nega e recusa a invenção de novos designs ou a transformação de uma forma em outra. Nesse sentido, o objetivo de um documento é alcançar satisfatoriamente uma estética de lógica e linguagem. Não há espaço para comentários, interpretações ou reflexões no produto final do documento, tais exercícios são deixados de lado no modelo pronto. Palavras e sentenças fazem parte do conjunto estético dos documentos, que as replicam repetidamente em sua extensão.

\section{Consideracõos finais: conflitos de conhecimentos}

Debates e reflexões sobre (des)encontros entre grupos indígenas ou regionais com aparatos burocráticos de políticas estatais, paraestatais e 
empresariais têm assumido grande interesse de pesquisas antropológicas recentemente. ${ }^{28}$ Algumas dessas pesquisas, ao focar nos modos como os seus interlocutores agem criativamente em relação a esses encontros, trazem à tona críticas aos modelos ocidentais de burocracia e política, permitindo-nos problematizar sobre como certas instituições se organizam e como realizam seus projetos de intervenção e mapeamento.

As situações de equivocações e desentendimentos entre os Xikrin e os engenheiros da Leme Engenharia, durante as apresentações dos resultados dos estudos, é mais um exemplo de como os regimes indígenas são considerados como um tipo de saber menos objetivo, com menor estatuto de veracidade científica em relação aos dados coletados pelos biólogos, às amostras de água coletadas, às leituras de máquinas sobre fluxo de vazão do rio. Os regimes de saber xikrin (kukràdjà) não foram considerados, na versão final dos estudos, como possuindo o mesmo estatuto dos dados apresentados pelos engenheiros e por isso foram obliterados por gráficos e modelos matemáticos que colocaram as teorias xikrin em situação de apagamento, em situação de anexo, com estatuto inferior por serem consideradas informações de caráter ilustrativo, menos importantes do que os gráficos de vazão do rio Bacajá.

A decisão dos técnicos-redatores do documento acerca do que esconder e mostrar no texto final dos Estudos Complementares do Rio Bacajá faz parte de um jogo ético e estético dos documentos enquanto artefatos (Riles, 2001). Nesse jogo, a expertise dos técnicos-especialistas assume maior materialidade do que as falas dos Xikrin, consideradas incapazes de gerarem dados concretos comprováveis.

Os engenheiros tornaram visíveis seus gráficos, seus cálculos de previsão hidrológica; enquanto que os Xikrin tornavam visíveis, ao longo do trabalho de campo das equipes dos estudos, seus modos de conhecimento, suas teorias de impacto com o secamento do rio Xingu, a relação hidrológica do rio

${ }^{28}$ Ver, por exemplo, Nahum-Claudel (2012) acerca da relação entre os Enawene e as práticas de negociação com agências de governo e empresas privadas para construção da usina Telegráfica na parte superior do rio Juruena; Coelho de Souza (2012), sobre um contrato entre os Kĩsedje (Suyá) e a empresa de caçados Grendene; Lima (2012), sobre os efeitos da popularização do kampô no meio urbano entre os Katukina; Andrello (2012), sobre o reconhecimento pelo Estado brasileiro da Cachoeira de Iauretê como patrimônio cultural do país e os efeitos na política-ritual dos grupos tukano e tariano; Cohn (2001), sobre a contraposição entre as noções xikrin de cultura e tradição e os conceitos de cultura e civilização do pensamento ocidental.

Horizontes Antropológicos, Porto Alegre, ano 22, n. 46, p. 159-188, jul./dez. 2016 
Xingu com o rio Bacajá, o saber, a cultura, o conhecimento dos Mẽbengôkre (Mẽbengôkre kukràdjà). Os Xikrin, ao mostrar seus conhecimentos, queriam a elaboração de um documento bonito/correto/verdadeiro (piôk nipey mejxtere) sobre o rio Bacajá e a região da Terra Indígena. Ao insistirem em registar em documento suas concepções e saberes para serem acopladas ao documento final dos estudos, os Xikrin, além de marcarem uma posição política de que seus conhecimentos eram tão e são ainda mais importantes que o dos engenheiros, agem para tentar controlar as equivocações entre os diferentes modos de conhecimento e mostrar seus conhecimentos (kukràdjà) como verdadeiros.

\section{Referências}

ALMEIDA, M. W. Caipora e outros conflitos ontológicos. Revista de Antropologia da UFSCar, São Carlos, ano 5, n. 1, p. 7-28, jan./jun. 2013.

ANDRELLO, G. Histórias tariano e tukano: política e ritual no rio Uaupés. Revista de Antropologia da USP, São Paulo, ano 55, n. 1, p. 291-331, jan./ jun. 2012.

COELHO DE SOUZA, M. S. O traço e o círculo: o conceito de parentesco entre os Jê e seus antropólogos. 2002. Tese (Doutorado em Antropologia Social)-Museu Nacional, Universidade Federal do Rio de Janeiro, Rio de Janeiro, 2002.

COELHO DE SOUZA, M. S. A pintura esquecida e o desenho roubado: contrato, troca e criatividade entre os kĩsêdjê. Revista de Antropologia da USP, São Paulo, ano 55, n. 1, p. 209-255, 2012.

COHN, C. A criança indígena: a concepção Xikrin da infância e do aprendizado. 2000. Dissertação (Mestrado em Antropologia Social)-Faculdade de Filosofia, Letras e Ciências Humanas, Universidade de São Paulo, São Paulo, 2000.

COHN, C. Culturas em transformação: os índios e a civilização. São Paulo Perspectiva, São Paulo, v. 15, n. 2, p. 36-42, abr. 2001.

COHN, C. Relações de diferença no Brasil Central: os Mebengokre e seus outros. 2005. Tese (Doutorado em Antropologia Social)-Faculdade de Filosofia, Letras e Ciências Humanas, Universidade de São Paulo, São Paulo, 2005. 
COHN, C. Belo Monte e os processos de licenciamento ambiental: as percepções e as atuações dos Xikrin e dos seus antropólogos. Revista de Antropologia da UFSCar, São Carlos, ano 2, n. 2, p. 224-251, jul./dez. 2010.

ELETROBRAS et al. Atendimento ao documento de considerações, questionamentos e recomendações ao AHE Belo Monte apresentado pelos movimentos sociais do rio Xingu. 2009. Disponível em: <http://www. socioambiental.org/banco_imagens/pdfs/Atend.\%20aos\%20Questio\%20 Mov.\%20Sociais_Ibama.pdf $>$. Acesso em: 20 ago. 2015.

FISHER, W. Rain forest exchanges: industrial and community on Amazonian frontier. Washington: Smithsonian Intituition Press, 2000.

FUNAI. Parecer técnico 21: análise do componente indígena dos estudos de impacto ambiental UHE Belo Monte. Brasília, 2009. Disponível em: $<$ http:// www.socioambiental.org/banco_imagens/pdfs/BeloMonteFUNAI.pdf $>$. Acesso em: 25 ago. 2015.

GORDON, C. Em nome do belo: o valor das coisas Xikrin-mebêngokre. In: SILVA, F.; GORDON, C. Xikrin: uma coleção etnográfica. São Paulo: Edusp, 2011. p. 207-222.

HARAWAY, D. Situated knowledges: the science question in feminism and the privilege of partial perspective. Feminist Studies, College Park, v. 14, n. 3, p. $575-599,1988$.

HARAWAY, D. When species meet. Minneapolis: University of Minnesota Press, 2008.

HULL, M. S. Documents and bureaucracy. Annual Review of Anthropology, Palo Alto, v. 41, n. 1, p. 251-267, 2012.

INSTITUTO SOCIOAMBIENTAL. Tabela de análise do cumprimento das condicionantes do componente indígena - processo de licenciamento ambiental da usina hidrelétrica de Belo Monte. 2013. Disponível em: $<\mathrm{http}: / /$ www.socioambiental.org/banco_imagens/pdfs/3.Tabela_de_Condicionantes. pdf $>$. Acesso em: 20 ago. 2015. 
KOHN, E. Natural engagements and ecological asthetics among the Avila Runa of Amazonian Ecuador. 2002. Tese (Doutorado em Antropologia)University of Wisconsin-Madison, Madison, 2002.

LEME ENGENHARIA. Aproveitamento hidrelétrico de Belo Monte: estudo de impacto ambiental. Rio de Janeiro: Eletrobras, 2009. $36 \mathrm{v}$.

LEME ENGENHARIA. Estudos complementares da bacia hidrográfica do rio Bacajá: volume VII: tomo IV. [S.1.]: Leme: Norte Energia, 2012.

LIMA, E. C. de. "A gente é que sabe" ou sobre as coisas katukina (pano). Revista de Antropologia da USP, São Paulo, ano 55, n. 1, p. 139-171, jan./ jun. 2012.

NAHUM-CLAUDEL, C. Enawene-nawe "potlatch against The state". Social Anthropology, Hoboken, v. 20, n. 4, p. 444-457, 2012.

OLIVEIRA, J. P. de; COHN, C. Belo Monte e a questão indígena. Brasília: ABA, 2014.

PAINEL DE ESPECIALISTAS. Análise crítica ao Estudo de Impacto Ambiental do Aproveitamento Hidrelétrico de Belo Monte. Organizado por Sônia Maria Simões Barbosa Magalhães Santos e Francisco del Moral Hernandez. Belém, 2009. Disponível em: $<$ https://www.internationalrivers. org/files/attached-files/belo_monte_pareceres_ibama_online_3.pdf $>$. Acesso em: 20 ago. 2015.

RILES, A. The network inside out. Ann Arbor: University of Michigan Press, 2001.

RILES, A. Documents: artifacts of modern knowledge. Ann Arbor: University of Michigan Press, 2006.

STRATHERN, M. Partial connections. Walnut Creek: Altamira: Rowman \& Littlefield, 1991.

STRATHERN, M. The tyranny of transparency. British Educational Research Journal, Oxford, v. 26, n. 3, p. 309-321, 2000. 
TSING, A. L. Friction: an ethnography of global connection. Princeton: Princeton University Press, 2005.

TURNER, T. Representing, resisting, rethinking: historical transformation of Kayapó culture and anthropological consciousness. In: STOCKING, G. Colonial situations: essays on the contextualization of ethnographic knowledge. Winsconsin: University of Winsconsin Press, 1991. p. 285-313.

TURNER, T. Os Mebengokre Kayapó: história e mudança social, de comunidades autônomas para coexistência interétnica. In: CARNEIRO DA CUNHA, M. História dos índios no Brasil. São Paulo: Companhia das Letras: Fapesp, 1992. p. 311-338.

VERSWIJVER, G. The club-fighters of the Amazon: warfare among the Kaiapo Indians of central Brazil. Gent: Rijksunivrsiteit, 1992.

VIDAL, L. B. Morte e vida de uma sociedade indígena brasileira. São Paulo: Editora da Universidade de São Paulo, 1977.

VIDAL, L. A pintura corporal e a arte gráfica entre os Kayapó-Xikrin do Catete. In: VIDAL, L. (Org.). Grafismo indígena: estudos de antropologia estética. São Paulo: Studio Nobel: Fapesp: Editora da Universidade de São Paulo, 2000. p. 143-191.

VIVEIROS DE CASTRO, E. Perspectival anthropology and the method of controlled equivocation. Tipiti: Journal of the Society for the Anthropology of Lowland South America, San Antonio, v. 2, n. 1, p. 3-22, 2004.

WILLERSLEV, R. Soul hunters: hunting, animism, and personhood among the Siberian Yukaghirs. Berkeley: University of California Press, 2007. 